\title{
НОВІ АСПЕКТИ НАРАТОЛОГІї: ІНТЕРПРЕТАЦІЯ ЕСЕЇСТИЧНОГО ТЕКСТУ
}

\author{
ТЕТЯНА ШЕВЧЕНКО \\ Одеський національний університет імені I. I. Мечникова, Одеса - Україна \\ shtn75@ukr.net; ORCID: 0000-0002-8118-9663 \\ NOWE ASPEKTY NARRATOLOGII: \\ INTERPRETACJA TEKSTU ESEJU
}

\author{
TETIANA SZEWCZENKO \\ Odeski Uniwersytet Narodowy imienia Ilji Miecznikowa, Odessa — Ukraina
}

\begin{abstract}
STRESZCZENIE. Artykuł powstał stworzony z potrzeby wszechstronnej analizy narracji w tekście eseistycznym. Autorka posługuje się narzędziem metodologicznym narratologii jako jednego z najbardziej aktualnych kierunków we współczesnej filologii oraz stosuje podejście narratologiczne wobec komunikacyjnej strategii w tekście eseju. Celem artykułu jest wprowadzenie i uzasadnienie pojęcia egzoginarratora, tzn. charakterystycznej postaci w eseju pisarza jako praktyce dyskursywnej. Na podstawie badania autorka dochodzi do wniosku, iż tradycyjna kategoria „narrator” w przypadku eseju pisarza może być stosowana jedynie z pewnym dystansem, ponieważ nie jest w nim obecna właśnie opowieść jako taka, lecz jest realizowana sytuacja opowieści przechodzącej w refleksje. Udowodniono, żeproces rozważania i proces opowieści w eseju łączą się w spójną całość. Nośnikiem tych czynnościjest narrator, który właśnie w eseju przybiera cechy myśliciela bądź wręcz występuje jako myśliciel. Wprowadzone pojęcie zostało przedstawione na materiale eseistyki ukraińskiego pisarza Stepana Prociuka.
\end{abstract}

Słowa kluczowe: esej, narracja, egzoginarrator, autor, praktyka dyskursywna

\section{NEW ASPECTS OF NARRATOLOGY: INTERPRETATION OF ESSAYISTIC TEXT}

\section{TETIANA SHEVCHENKO}

Odesa I. I. Mechnikov National University, Odesa — Ukraine 
ABSTRACT. The article's relevance lies in the need to understand the peculiarities of narrativity in essays. The article is written within the scope of narratology as one of the most relevant disciplines in modern philology, narrative approach to communicative strategies in essay is used. The article's goal is to introduce and argumentate the concept "exogynarrator", narrative instance in essay as a discursive practice. As a result of the research, it is concluded that 'narrator' as a traditional category in epic works, can be applied to a writer's essay conventionally: in the essay there is no actual story or narration, etc., except that it may be possible if narration turns into mediatation. It is proven that the process of meditation and the process of narration in an essay become a single entitiy. The bearer of these actions is the narrator, who in the essay acquires features of a thinker or turns into him. The introduced concept is illustrated based on the essays written by Ukrainian author S. Protsiuk.

Key words: essay, narrative, exogynarrator, author, discursive practice

$\prod$ оява нових культурних поворотів наприкінці XX ст. - на поч. XXI ст. зумовлена передусім самими інтенціями більшості гуманітарних наук, орієнтованими на розрив із чинними традиціями. Будучи складником постмодерністського мислення, вони вможливлюються через перегляд стійких принципів розгляду певних явищ культури, адже “поворот” означає насамперед новий фокус найактивніших, системних, усебічних, багатоаспектних й одномоментних досліджень того, що завжди латентно існувало. Такі повороти найчастіше існують у чинних традиціях у певних галузях культури. Напр., просторовий поворот, що виник на грунті семіотичних досліджень (Ю. Лотман, В. Топоров, В. Іванов), чи перформативний, що сформувався на основі аналізу й інтерпретації нових видів мистецтва (Д. Остін, Д. Батлер, Д. Брахманн-Медик). Інші повороти в гуманітарних науках — тілесний, іконічний, інтерпретаційний, перекладацький, рефлексивний - мають схожу генезу й природу існування.

Наративні дослідження вже пройшли не один етап розвитку. Учення, уведене Ц. Тодоровим 1969 р., зазнало змін упродовж декількох етапів під впливом структуралістських, постструктуралістських течій, тож дослідники сучасності (Д. Герман, Дж. Принс, М. Р’ян) уже виділяють класичну (Ф. Соссюр, Р. Барт, Ц. Тодоров, Ж. Женнет, Ж. Пуйон, К. Бремон, С. Четмен, В. Бут, Ф. Штанцель) і посткласичну наратологію (Д. Герман, Дж. Принс, Ж.-М. Шеффер, В. Тюпа та ін.). Якщо наратологія так званого класичного періоду (к. 60-х рр. - 70-ті pp. ХХ ст.) була зосереджена на сутностях і засобах визначення наративу, пошуках спільного та відмінного між ними, то посткласична наратологія (з к. 80-х рр. ХХ ст. і до сьогодні) вивчає наратив більшою мірою як процес, а не як результат. Крім того, теорія оповіді стала потужним ресурсом соціально-культурних практик, комунікативних процесів, що дало змогу говорити власне про наратологію як культурний поворот. Напр., В. Вольф одним з перших заявив, що необхідно концептуалізувати наративність у трансмедійних межах [Wolf 2002: 28]. Дотримуючись кон- 
цепції Дж. Принса [Prince 1982], він виявляє не наявність або відсутність наративності, а міру іiі вияву у творі, переглядаючи традиційне поняття "наративність”, доповнюючи його положеннями гнучкої концепції засобу вираження (medium) та інтегруючи уявлення про засоби вираження (media) в систематичний опис наративів. Крім того, оповідь як спосіб пізнання, тип дискурсу й ресурс для художнього письма та інших форм комунікації стає своєрідною точкою перетину дослідницьких можливостей когнітивної та соціальної психології, лінгвістики й літературознавства, формуючи новий напрям - когнітивну наратологію.

Важливий аспект наративних студій останнього часу - анаративні складники тексту у взаємодії з наративними. В окремих випадках, як це не парадоксально, наратив відходить на другий, третій плани дослідження, поступаючись не подієвим, не оповідним і не сюжетним (фабульним) аспектам твору. У таких працях важливий саме контекст наративу. Відтак наративна методологія в класичних своїх зразках щодо такого типу тексту може бути застосована з певним рівнем умовності. Передусім акцентовано увагу на анаративних аспектах, як-то дескриптиві, ітеративі, ментативі тощо.

Зазначмо, що наратологія як теорія оповіді, звісно, більшою мірою адаптована в лінгвістиці й літературознавстві, що всебічно вивчають можливості художнього й нехудожнього слова. Сучасна літературознавча наука має значні здобутки вивчення численної кількості літературних жанрів і мовленнєвих практик, специфіка наративізації кожної з них описана більш-менш усебічно й системно. Між тим дискурсивні підходи відкривають нові аспекти вивчення новітніх змістовних форм і практик, що виникають, напр., унаслідок родо-жанрових взаємовпливів, міждисциплінарної взаємодії, міжмистецьких секвенцій, медійних і художніх інтерференцій. Відповідно наративні здобутки навіть за майже півстолітню історію наукових пошуків не завжди можуть бути адаптовані й застосовані. Так, показовою є дискурсивна практика есе ${ }^{1}$, надзвичайно популярна в сучасній українській літературі серед письменства, наукової й медійної спільноти.

Сьогодні есеїстика дедалі активніше набуває художніх ознак, стаючи літературним твором, таким, що стоїть в одному ряду з повістю, новелою, оповіданням. Ці процеси суголосні позиції Р.Ніча, який наголосив, що „в сучасному дискурсі есеїстичний процес мислення $є$ неподільно пов' язаним 3 процесом мовної артикуляції, мислення тут виступає засвоєним мовленням; пізнання - інтерпретацією, правда — процесом, пошуком" [Nycz 2002: 39] (переклад автор. - Т. Ш.).

\footnotetext{
${ }^{1}$ Дискурсивну (мовленнєву) практику розуміємо як художньо й соціально-культурно обумовлений комплекс процесів продукування й розповсюдження певних видів суб'єктивно-рефлексивної інформації, що художньо відтворена й асоціативно оформлена у вигляді окремих текстів на актуальні для автора внутрішні й зовнішні проблеми з метою оприлюднення.
} 
Отже, за В. Шмідом, предметом вивчення наратології є наратив, або оповідь, побачена в аспекті певних подій та $з$ огляду на їхніх учасників [Шмид 2003: 18]. Відтак головним у вихідному положенні цієї методології є власне подієва природа оповіді. Напр., Ж. Женнет писав, що „без труднощів визначимо наратив як репрезентацію події чи послідовності подіï” [Gennete 1982: 127] (переклад автор. - Т.Ш.). Головною категорією наратології є також категорія оповідача, або наратора, який констатується в тексті й сприймається читачем не як абстрактна функція, а як суб'єкт, обов'язково наділений певними антропоморфними рисами мовлення й мислення; виділено цілу низку його видів у художніх творах, напр., за участю в дієгезисі, активністю в дії, залежно від ситуацій, у яких він перебуває, за ступенем виявлення, особистісними якостями, гомогенністю, простором тощо.

Однак сучасне письменство дедалі активніше вдається до творчості, у якій події зредуковано до мінімуму, а основне текстове полотно становлять потік свідомості, рефлексія, медитація, роздум. Ідеться насамперед про безсюжетну психологічну новелу й есе, твір, що за своєю природою не передбачає спеціального зображення дійсних чи фіктивних подій, “історій”, хіба що можливе їхнє фрагментарне вкраплення в текстове полотно з метою проілюструвати думки чи обсервації в процесі міркування. У цій ситуації насамперед ідеться не про власне наратив, а наративний дискурс - те, як ці події репрезентовані, осмислені, украплені в тканину розмислів та висновків. Адже письменницьке есе - твір не наративний, а ментативний за своєю суттю, тобто позначений референцією „до мислення як такого і його мовленнєвої форми” [Максимова 2012], оскільки складається з міркувань різного характеру, його підгрунтя медитативність і рефлексія у всьому своєму розмаїтті: ретроспективна, проспективна, інтроспективна. 3 моменту появи есе як твору нового типу 3 украй послабленим сюжетним началом, причинними зв'язками, обмеженою подієвістю й посиленням авторського мисленнєвого потенціалу, презентованого вербально, його ментативна природа хоч і не декларувалася, проте усвідомлювалася, адже у творах, репрезентованих ще Спробами $1580 \mathrm{p}$. М. Монтеня, передусім увагу привертає не стільки подієвість, скільки ії осмислення, міркування, спричинені ситуаціями й подіями, чи не стільки сам досвід, скільки спроба його вербальної обсервації, адже на очах читача народжувалися ідеї, інкрустувалися розмисли, “оголювалася" авторська свідомість. I, що важливо, тут головним був не результат осмислення, а сам процес цього, що не підпорядковувався жодним канонам і правилам.

Отже, якщо наратив — це клас подвійно подієвих дискурсивних практик, що поєднує в непочленовану якість висловлювання - референтне й комунікативне, то ментатив — „висловлювання з розвинутою рецептивною інтенцією і креативною конструкцією”, що „не просто інформує про стани чи процеси буття й мислення, але передбачає — як наслідок комунікативної 
події - певну ментальну подію (зміну картини світу) у свідомості адресата" [Дейк 1989: 49]. Відмінність між наративом і ментативом пояснює В. Тюпа: якщо в наративі дві події постають як єдність - подія, про яку йдеться у творі, і подія самої розповіді, то ,,референтним змістом ментативних висловлювань виступає не подієва інтрига життя, а процесуальна законодоцільність буття, що породжує експліцитну інтерпретаційність” [Тюпа 2008] (переклад автор. - Т. Ш.). Тому в цій ситуації спеціально закцентовано увагу на мисленнєвому началі твору як процесі, живому характері думки, їі особистісному тлумаченні, трактуванні. Цей процес відбувається прямо на очах читача й цікавий не так результатом, як процесом мислепородження, що, напр., у варіанті есе стає підгрунтям власне текстопородження: „У наративі панує референція до «протяжності» хронотопу, в ментативі - до ментальної ситуації: до мислення як такого у його мовленнєвій формі” [Кузнецов, Максимова 2007: 56] (переклад автор. - Т. Ш.).

У письменницьких есеїстичних практиках, як видається, використовують i ментативний, і ментативно-наративний типи розгортання тексту. „Конвергенція різноманітних типів висловлювання, зумовлена багаторівневою системою асоціативних рядів і принципово дискретним характером поєднання структурно-семантичних елементів тексту в зображенні тої чи тої ментальної події в есе, привертає увагу читача-інтелектуала, готового взяти участь у розгадуванні художнього ребусу й наповнити його власною рефлексивно-раціональною пульсацією” [Шевченко 2018: 151-152]. Проте подія й розповідь про неї як такі в есеї не принципові апріорі: переважно вони стають поштовхом для розгортання думки, своєрідною точкою відліку. Отже, подієвість в есе не так дотичність до буття, як вичленовуване людиною інобуття, своєї власної реальності, опозиційної до всього, що є. В есе як особливому типі розгортання тексту не переповідаються події в той чи той спосіб. У такому тексті відтворюється задум розгорнути думки за допомогою подій чи без них, “запустити” сам процес мислетворення, рефлексії як такої, де думка лише інтонується подієвим началом, що в тексті виконує допоміжну функцію.

Оскільки ментативну природу письменницького есе науковці тільки-но починають осмислювати в літературознавстві нового часу, то застосування чинних методик до неї часто потребує їхнього адекватного адаптування й упровадження. Цілком очевидно, що цей твір зітканий насамперед 3 висловлювань 3 ментальною референцією - ментативів, і тільки меншою мірою його доповнюють декларативи, ітеративи, дескриптиви, наративи, перформативи тощо, та й функція їхня не тотожна у творах власне художніх.

Ураховуючи зазначене вище стосовно того, що есе - твір ментативний, ненаративний за своєю природою, слід зважати на умовність застосування набутків чинної наратології щодо нього. Сучасний дослідник есе має звертати увагу на анаративні елементи есе, що в ньому домінують, поступаючись наративу, адже 
дискурсивна практика есе передбачає насамперед ментальну референцію як референцію до мислення як такого, вираженого вербально. Есе окреслює художню картину світу, оперуючи парадоксами, думками, висновками, а не фактами й подіями, послідовністю їхнього презентування. Для читача й автора важливими в есе $\epsilon$ не події (історії, епізоди), про які розповідається, а власне сама подія, процес розповіді, що провокує роздуми, які є найціннішим у тексті, причому референтна подієвість пов'язана не стільки із зовнішнім контекстом його появи, скільки 3 комунікативною подією його актуалізації, структурно закладеною в самих висловлюваннях есе. Долучаючись до такої подієвості й таких розмислів, читач есе спостерігає процес народження думки, усвідомлює іï “живий” характер і розвиває ії. Однак цілком очевидно, що природа думки має бути опредметненою, тобто такою, що прив'язана до когось або чогось, хто й що мали місце в реальному світі, тобто до людей, фактів, явищ, подій, ситуацій, усього дотичного до матеріального світу. Відтак усі зазначені маркери реальності - це джерела народження ідей, їхні дороговкази й підгрунтя. Заперечити їхню важливість у текстах, зітканих із суцільних рефлексій і медитацій, - означає відхилитися від природи есеїстичного тексту як такого, адже його центрованість, використання міркування й опису як основних функційно-смислових типів мовлення, підкреслений індивідуально-авторський вибір мовних засобів, обмежена, але помітна подієво-темпоральна (розповідна) лінія, поєднана з унаочненням мисленнєвого процесу, і відображення перерахованого вище як цілісності вирізняє цю мовленнєву практику з-поміж інших творів сучасної літератури.

Слід ураховувати, що в есе конотація наративу відрізняється від звичного в традиційних епічних жанрах пояснення понять “розповідь", “оповідь”, як і поняття "наратор" не збігається з відомим "розповідач новели чи повісті". Тут наголошують не на події, а на "історії”, що мала місце ще до текстуального викладу, а розповідач цікавий не щодо участі в ланцюгу подій чи їхнього інтерпретування, а виключно стосовно його можливості й здатності ставати дієвим філософом і наочним обсерватором на підставі презентованих нечисленних подій чи без цього. Сам цей процес $є$ імпліцитним, непомітним, і саме тому наратив стає досить зручним для трансляції неявних утручань розповідача в хід історії, ті чи ті перипетії (напр., у процесі переставлення епізодів, розв'язки чи зав'язки). Додаймо, що таким же імпліцитним $є$ й процес перетворення розповідача на мислителя, а то й просто існування його як людини, яка мислить і вряди-годи у своїх міркуваннях відволікається на окремі оказії буття.

Водночас, визначаючи першорядну роль ментативу як події думки в дискурсивних практиках есе, не можемо повністю викреслити в них факти, епізоди дійсності, що стають предметом осмислення, як і певний причиново-наслідковий ланцюг між ними, описаний у текстах. Часто розповідь 
про ті чи ті події стає підгрунтям формування ментативу, певним вектором мислетворення. Фрагменти есе, що мають наративний характер, спрямовані на презентування інформації в розвитку. У них зрідка йдеться про “чисті” факти. Перевага надається подіям, що передбачають обов’язкову причетність людини до відміченого нею факту чи сукупності фактів. При цьому вона може бути не стільки соціально-ситуативна, скільки особистісна, а тому подія не просто ментальна, а принципово аксіологічна. Додаймо, що в есе як мовленнєвій практиці йдеться виключно про такі ситуації, адже есе - твір особистісний, націлений на презентування власного “я" саме крізь ці ментальні події.

З урахуванням викладеного вище зазначмо, що актуальним постає питання про те, як кваліфікувати, позиціювати й номінувати авторське “я” в есе, адже це не наратор, не сам автор, а його художнє втілення, виявлене в міркуваннях, розмислах і висновках, відмінне від наявного в романі, новелі чи повісті. Проте специфіка саме письменницького есе як художнього твору не дає змоги окреслити це “я” виключно як мислителя, адже митець презентує потік міркувань, інтонований саме літературними акцентами, витоки яких у його основній письменницькій діяльності - епічній, поетичній чи драматичній, i сліди цієї творчості простежуються в есеїстичній спадщині літератора, хоче він того чи ні. Отже, традиційна категорія “наратор” (оповідач, розповідач) щодо есе може бути застосована лише частково, адже в цій ситуації не йдеться про власне оповідь. Тут акцентовано увагу на міркуваннях у процесі, дії, розвитку через наратив чи без нього. Категорія “наратор" прийнятна в цій ситуації хіба що як „створена фігура, яка належить усьому цілому літературного твору” [Шмид 2003: 37] (переклад автор. - Т.Ш.) або як той, „хто не лише функціонально впорядковує текстову структуру твору, але й виявляється спробою досягнути внутрішньопсихологічного порозуміння спочатку автора 3 його історичністю, а згодом і читача з цілісним культурним середовищем. Гра наратора з читачем - це своєрідне запрошення до комунікації, спроба примирити всезнання та всеправність автора із прагненням до самопривласнення чужого досвіду читачем” [Мацевко-Бекерська 2011].

Однак першорядна функція “традиційного” наратора згідно 3 положенням класичної наратології, - створення наративного дискурсу, ведення наративу, тобто оповіді, іншими словами, переповідання подій i вчинків персонажів, виклад їх у тій чи тій послідовності з урахуванням певних позицій, обраних письменником. Важливим тут є сам процес оповіді, акцент на тому, хто, як і в який спосіб переповідає (компонує, вичленовує, акумулює) події, явища, ситуації, героїв, образи, що вибудовуються в певний сюжет чи фабулу. Усі вони укладаються в “історії”, тобто відібрані події й поєднані з подібними. Сам вибір подій і ситуацій оформлює власне нарацію (процес оповіді), їхнє презентування становить наратив (результат, характер, ракурс оповіді) твору. 
Тут і виникають труднощі із застосовуванням уже класичної категорії “наратор" щодо дискурсивної практики есе. Адже в цій мовленнєвій практиці оповідь - вторинна, а міркування - первинне, відтак назвати есеїстичне "я", утілене в тексті, наратором можна хіба що як того, хто протиставляється конкретному, реальному, біографічному авторові. Автор есе і його художнє втілення - не тотожні образи, хоч якими би близькими вони не були. Так, автор новели та його образ у ній, як і автор есе та його образ у ньому, — цілком відмінні образи: образ автора новелістичного твору може бути цілком вигаданим, тоді як образ автора в есе все-таки близький до реального, біографічного автора. Тут цілком доречно пригадати художню формулу цього феномена, окреслену ще зачинателем жанру есе М. Монтенем у книзі Спроби 1580 р. про те, що ,зміст цієї книги — я сам”.

3 моменту появи есе в європейській літературі й першого наукового осмислення цього жанру й дискурсивної практики з урахуванням сучасного підходу до неї в науковій літературі не припиняються дискусії щодо того, як називати художнє втілення автора-есеїста в його ж тексті. Перелік цих наукових номенів може скласти не одну сторінку тексту. Пропонуємо лише відібрані нами, тобто ті, що є найчастотнішими: фiгура оповідача / мислителя; оповідний суб'єкт; оповідна інстаниія; оповідна субстаниія; носій свідомості; носій висловлювання; суб 'єкт висловлювання; суб 'єкт свідомості; носій мовлення; образ автора; “образ” автора (у лапках); образ “я”; вторинний автор; авторська інтенція; автор, узятий у приватному модусі; автор, який використовує себе як об 'єкт аналізу тощо. Найчастіше дослідники вдаються до метафор й описовості, говорячи про авторське втілення в есе або ж знов-таки метафорично описують його, апелюючи до недосконалості чинної термінології в цій сфері. Так, Г. Прохоров украй обережно зауважує, що „оповідач художньо-публіцистичних єдностей наділений рисами, що споріднюють його з оповідачем (наприклад, експлікованість), але в той же час — і рисами образу автора (наприклад, здатність говорити про твір). [...] Ми лише констатуємо відмінність між «первинним автором», «вторинним автором» (оповідачем / розповідачем / образом автора) і героєм, що зберігається в такого роду літературі" [Прохоров 2013: 11] (переклад автор. Т. Ш.). А. Маслаков наголошує, що „носій мовлення не може бути окреслений як «оповідач», оскільки його позиція - позиція акцентовано суб'єктивної і співпереживальної відтворюваної ситуації особистості” [Маслаков 2010: 121] (переклад автор. - Т.Ш.), при цьому він не пропонує свій варіант його найменування в есе. К. Зацепін у різних джерелах пропонує різні дефініції цієї субстанції. Ось одна з них: „Бажано говорити про експлікацію індивідуальної думки у вигляді множинності відносин суб' єктивності того, хто пише, зовнішньо оформлених граматичною формою «Я» як фокусом сил, котрі проблематизують, зводять разом того, хто пише, мову і предмет вираження" [Зацепин 2006: 16] (переклад автор. - Т. Ш.). Наведені позиції лише ще раз 
підтверджують неможливість прямого застосовування набутків наратології саме до есе як літературних творів, підтверджують нагальну потребу пошуку точнішого найменування й науково обгрунтованого позиціонування есеїстичного втілення автора в текстах. Результати логічного текстового аналізу засвідчують, що традиційна для епічного твору категорія “наратор” (В. Шмід, Ж. Женнет, Б. Корман, В. Тюпа) може бути застосована для письменницького есею 3 певним рівнем умовності: в есе відсутня ситуація власне розповіді, оповіді тощо, хіба що вона можлива тільки як ситуація оповіді, що переходить у міркування. Поняття “мислитель" теж може бути застосоване щодо есе частково: адже письменник не філософ, він митець, який на нових платформах відшукує інші можливості виконання завдань естетичного відтворення дійсності вербальними засобами. Тому для есе як дискурсивної практики авторка запропонувала поняття “екзогітатор” або “екзогінаратор” (лат. excogitatoris - мислення, cogitare - розмірковувати, narrator оповідач). Ідеться про оповідача, який саме в есе набуває ознак мислителя, розмірковувача або ж перетворюється на мислителя, оповідача. Він має багато спільного з біографічним автором, однак не його абсолютною копією, оскільки постає в різних обличчях та образах. Це оповідач, який трансформується в мислителя буквально на сторінках тексту, наочно, живо через переповідані певні історії чи без них. Власне оповідні фрагменти твору можуть слугувати поштовхом до міркувань, а можуть вплітатися в текстове полотно, зіткане з розмислів та висновків.

Сучасна українська есеїстика, що активно розвивається, презентована різними видами творів: ментативними, у яких події, що переповідаються, максимально зредуковано, їх практично немає, тексти є суцільним потоком роздумів, утілених у художню форму (Г. Пагутяк, К. Москалець, А. Бондар, Т. Прохасько), наративно-ментативними, у яких ідеться про описані наратором події, що поступово перетворюються на потік міркувань, тому в таких есе наратор (оповідач) перетворюється на екзогітатора (мислителя), а відповідно, доречно говорити про екзогінаратора як про авторське втілення в цих есе (Ю. Андрухович, С. Жадан, О. Забужко, Є. Кононенко, А. Любка, С. Процюк), власне наративними, у яких наратив дуже важливий, він навіть візуально займає багато місця, однак усе одно він підготовлює ментативну частину в есе, що $є$ найціннішою для читача, адже переповідані сюжети й історії лише готують платформу для міркувань різного характеру, прикметні своєю парадоксальністю, незаангажованістю, різновекторністю. Це більшою мірою стосується есеїстики в масових виданнях, що потім може отримати друге життя в письменника у вигляді збірки (В. Жежера, С. Пиркало, М. Рябчук та ін.).

Простежмофункції й особливості прояву екзогінаратора в есеях Тініз 'являються на світанку та Страх смерті відомого сучасного письменника Степана Процюка, автора психоаналітичних романів, лауреата численних національних 
літературних премій, автора повістей, збірників самобутніх есе: Канатохідиі, Аналіз крові, Тіні з 'являються на світанку, Трикутник тощо, популярних серед сучасної читацької аудиторії. Так, есе Тіні з'являються на світанку, що стало назвою однойменної збірки, не випадково ії відкриває: розміщення його в “найсильнішій позиції” книги окреслює й основне поле розмислів у ній як цілому. Есе Страх смерті продовжує розвиток мотивів про смерть як зміну стану свідомості, розпочатий у попередніх есеїстичних збірках автора.

Отже, екзогінаратора в есеях С. Процюка Тіні з'являються на світанку і Страх смерті можна схарактеризувати як такого, який демонструє потік думок, власне процес міркування, доповнюючи його вряди-годи поодинокими історіями, що й переключають читацьку увагу, і тримають ії одночасно. В есеях ідеться про неминучість смерті, страх перед цією приреченістю, окресленою багатоаспектно. Торкаючись таких непростих тем, оповідач / мислитель спокійно їх осмислює, усебічно узагальнює, спираючись на власний досвід та досвід інших видатних постатей минулого й сучасності. Зрештою, в есеях наголошується, що смерть - онтологічне й екзистенційне явище, міркування про неї дає змогу людині глибше, тонше пізнати власну сутність, оцінити сенс чинного існування, змінити щось у житті в конкретну мить у разі потреби. Обидва есе пов'язані не тільки спільністю мотивів, а й художнім утіленням автора в них: друге есе, розміщене в збірці, було написане раніше, ніж перше, адже в першому йдеться про страх смерті й навіть подано короткі міркування-доповнення й розмисли у зв'язку з його первісним оприлюдненням й отриманням першої читацької реакції на нього.

Сконцентрувавшись повністю на мотивах неминучості, розглянувши думки великих про смерть, автор есе через презентоване "я" зрештою вибудовує свій танатологічний код, прикметний парадоксальністю: „Трагедійність індивідуальних смертей може зіставитися лише з повнотою життів. Як магічний амулет чи просвітлену мудрість згадую фразу одного з античних стоїків: «Роздумуй про смерть, якщо хочеш навчитися жити». І в цій вічній школі - зі своїми відмінниками й невдахами - $є$ істинний сенс, що освітлює наші тьмяні манівці” [Процюк 2011: 57-58].

Художні переходи від розповіді до рефлексії у творах С. Процюка переважно ледь проглядні, прозорі, розмиті. Спершу відбувається пошук точок самоідентифікування з тими сюжетами, що поетапно викладені (,я повернувся до батьківської хати начебто таким, як до цієї події. Але водночас інакшим”). Якщо йдеться про сторонню людину, ідентифікування відбувається на рівні “свій - інший”, якщо йдеться про історії з власної біографії, то йдеться про дотичність колишніх і дотеперішніх цінностей письменника. Далі відбувається редукція зовнішньої подієвості, перетворення іії на внутрішню подієвість шляхом знову ж таки самоідентифікування з тим, що по-своєму приймає внутрішнє “я” автора, відповідно відкинувши все зайве (,після того випадку 
Я $[\ldots]$ довго вдивлявся у холодну велич нічного неба"). Наступний крок рефлективне перетворення реальності, спершу як чуттєве “овнутрішнення" подій, що вже вкарбовуються у свідомість як щось органічне (,„це була лише одна зі сторін єства малолітнього відшукувача смислів"). Його можуть доповнювати процеси представлення й активізування уяви (,я почав уявляти велетенське коло, де танцюють і радіють всі без винятку люди"). Далі відчуття розчиняються, породжуючи міркування як поступове вибудовування концепції ідентичності - думок, мислеобразів, висновків, як вербалізація нового авторського знання, презентованого художніми засобами (,Я вперше пережив тоді болісне почуття солідарності з людиною із минулої епохи, іншого віку і статі [...]. Якщо би такі стани почали провідувати мене частіше, то не впевнений, чи зараз я би писав цього есея [...]”) [Процюк 2011: 20].

В аналізованих есе наративні вкраплення в ментатив про смерть більшою мірою автобіографічні: у тексті чимало відведено особистим одкровенням письменника, розповідям про його “відкриття” смерті, особисті осяяння в цих неминучих питаннях, що перед собою ставить кожна людина. Короткі сюжети про смерть близьких, переживання історій, розказаних іншими, переростають у філософські узагальнення про те, що „є лише життя, у якому нам потрібно так багато відчути і зрозуміти, хоча би заради вічного поклику тремтливої зірки дитинства [...]” [Процюк 2011: 42].

У представлених мікронаративах (випадок у студентському житті, смерть брата Ігоря, відвідування могили матері тощо) оповідач $є$ переважно дієгетичним: він і суб'єкт оповіді, адже мовить про себе, однак може бути й ії об'єктом, коли йдеться про власну участь у переповіданих подіях (напр., історії про школу, навчання в університеті). Цілком очевидно, що спеціального акцентування на цих історіях не відбувається — це лише компонент висловлювань з розвинутою рецептивною інтенцією й креативною конструкцією, які не просто інформують про стани чи процеси буття й мислення, але передбачають як наслідок комунікативної події-певну ментальну подію (змінення картини світу) у свідомості адресата. Ідеться про нарацію від першої особи однини, що зрідка може переходити в оповідь від третьої особи множини в ситуації узагальнення сказаного й осмисленого: „Я не намагаюся монополізувати істину, бо я сміявся б сам із себе. Ми лише можемо ії шукати, відмовляючись від будь-яких форм сучасної гедоністичної релігії” [Процюк 2011: 49].

Основна ж частина творів - ментативна, що повністю спирається на рефлексивну свідомість суб'єкта мовлення. Він постійно перетворюється із суб' єкта дієгезису на суб'єкта думки й, навпаки, презентується оповідачем, обсерватором і мислителем-філософом. Процес, пов'язаний з відображенням характеру його рефлексії, передає позицію й безпосереднього оповідача подій, і того, хто спостерігає за цими подіями ззовні. Саме тому він і починає набувати рис мислителя (екзогітатора), адже моделює філософсько-художню 
танатологічну концепцію у творах Страх смерті й Тіні з являються на світан$\kappa y$ шляхом вилучення зі свідомості подій, фактів, роздумів, що й породжують розгорнуті рефлексії. У модусі ментативної оповіді постає не просто внутрішній світ, стихія переживань, почуттів оповідача. Тут важлива сама ментальна подія осягнення проминальності часу, крихкості людського буття, що стає можливою через розказані міні-історії чи без них. Цікаві самі переходи, перетікання станів есеїстичного “я” у творі: наратор (оповідач) перетворюється на екзогітатора (мислителя) й описані кризові обставини сприймає як можливість саморозвитку. Переходи на рівні тексту від наратора до екзогітатора виявляються в мовних конструкціях (порівн.: „тоді, до речі, я не зовсім це розумів”; „можливо, я дещо ідеалізую цього бухгалтера і його форму маніакальності”; „Далі нічого не тямлю. Через кілька днів до мене прийшло перше усвідомлення тліну і жаху”). У таких переходах частими є антиномії 'там — тут', 'тоді тепер' тощо. Переходи від екзогітатора до наратора в текстах репрезентовано такими мовними конструкціями: „а в житті направду не легко відшукувати сенс”, „у будь-якому разі мене довгі роки не покидало відчуття якогось дивного заціпеніння”, „я чудово усвідомлюю свої скромні читацькі можливості в контексті цієї проблеми". Часто перехід - це заперечення, спростування позиції, висловленої перед цим. Цілком очевидно, що переходи укладаються в таку схему: “оповідь — тлумачення / коментування - рефлексія" чи “міркування - вичленовування ключових понять - тлумачення - оповідь на підставі наведених вище позицій”. Такі переходи формування думки й образності можуть повторюватися по всьому тексту неодноразово. Постає питання: тож в есе йдеться про наратора чи екзогітатора, якщо ці інстанції постійно чергуються з різним ступенем інтенсивності? У цій ситуації, як видається, логічно розмірковувати про вияв екзогінаратора, оскільки він здатен якнайточнішепередати ціпереходи. Винесення в препозиціюелемента “екзогі” в номінації екзогінаратор указує на пріоритетність носія свідомості в есе.

Отже, упроєкції на есе доцільно говорити про екзогінаратора як спеціальну категорію в наратології в есеїстичному тексті, адже в ній поєднано ознаки оповідача й мислителя одночасно, бо процес міркування й процес оповіді стають єдиним непочленованим цілим, як це засвідчив аналіз текстів С. Процюка. Елементи нарації й процесу творення ментативів невіддільні один від одного. Саме вони й породжують специфічні есеми на кшталт того, що “старість — це трагіпародія дитинства”, “стихійний «епікуреїзм»є нічим іншим, ніж безперервною втечею від вивертів власної свідомості”, а “щастя — не назовні, а всередині”. Як показав аналіз творів, екзогінаратор наділений рисами автобіографічності: життєпис письменника переважно й стає тим матеріалом, що укладає ментатив тексту, який повністю спирається на рефлексивну свідомість суб'єкта мовлення. Звісно, це може постати предметом подальших наукових досліджень. 


\section{Список використаної літератури}

Дейк ван Т., Язык. Познание. Коммуникация, Москва: Прогресс, 1989.

Зацепин К., Эссе как коммуникативная форма: проблемы чтения (на материале современной эссеистики), автореф. ... канд. филол. наук, Самара 2006.

Кузнецов И., Максимова Н., Текст в становлении: оппозиция „нарратив-ментатив”, „Критика и семиотика”, 2007, № 11, с. 54-67.

Максимова Н., Понимание в диалоге: текстовые модели ментатива, Новосибирск: НИПКиПРО, 2012, [в:] Электронный pecypc: https://www.metod-kopilka. ru/tekstovaya_kultura_modeli_rassuzhdeniya_v_russkom_tekste._monografiya-26564.htm (01.03.2019).

Маслаков А., Носитель высказывания в поэтических эссе О. Э. Мандельштама и М. И. Цветаевой, „Известия вузов. Северо-Кавказский регион. Общественные науки", 2010, № 6, с. 120-123.

Мацевко-Бекерська Л., Типологія наратора: комунікативні аспектихудожнього дискурсу, „Науковий вісник Миколаївського національного університету імені В. О. Сухомлинського. Філологічні науки (літературознавство)”, 2011, № 8, [в:] Електронний ресурс: http://litzbirnyk.com.ua/wp-content/uploads/2013/11/31.4.8.pdf (01.03.2019).

Прохоров Г., Поэтика художественно-публичистического единства (на материале литературы периода классического посттрадиционализма), автореф. ... д-ра филол. наук, Москва 2013.

Процюк С., Тіні з'являються на світанку, Луцьк: Твердиня, 2011.

Тюпа В., О границах нарратологии, „Проблемы нарратологии и опыт формализма / структурализма", Санкт-Петербург 2008, [в:] Электронный ресурс: http://papusha.at.ua/ tiupa-o_granicax_narratologii.doc (02.03.2019).

Шевченко Т., Есе як дискурсивна практика: до постановки проблеми, [в:] Срібний вік: діалог культур, зб. наук. ст. за матер. IV Міжнар. наук. конф., присв. пам'яті проф. С. П. Ільйова, Одеса 2018, с. 290-303.

Шевченко Т., Удовольствие от чтения эссе или о причинах востребования жанра, [в:] Czas wolny, rozrywka, używky w najnowszej literaturze rosyjskiej, pod redakcją L. Kality, Gdańsk: Wyd-wo Un-tu Gdańskiego, 2018, c. 147-163.

Шмид В., Нарратология, Москва: Языки славянской культуры, 2003.

Baroni R., Françoise R., Narrative Sequence in Contemporary Narratology, Columbus: The Ohio State University Press, 2016.

Genette G., Figures of Literary Discourse, New York 1982.

Nycz R., Literatura nowoczesna: cztery dyskursy (tezy), „Teksty Drugie”, 2002, no 4.

Prince G., Narratology: The Form and Function of Narrative, Berlin 1982.

Todorov Tzv., Grammaire du Décaméron, Paris: Mouton, 1969.

Wolf W., Das Problem der Narrativitat in Literatur, bildender Kunst und Musik: Ein Beitrag $z u$ einer intermedialen Erzahltheorie, Erzahltheorie transgenerisch, intermedial, interdisziplinar, hrsg. V. Nunning, A. Nunning, Trier 2002. 


\section{Spysok vykorystanoi literatury [References]}

Dejk van T., Yazyk. Poznanie. Kommunykaciya [Language. Cognition. Communication], Moskva: Progress, 1989.

Zacepin K., E'sse kak kommunikativnaya forma: problemy chteniya (na materyale sovremennoj e'sseystiki) [Essay as a Communicative Form: Problems of Reading (Based on Modern Essays], avtoref. ... kand. filol. nauk, Samara 2006.

Kuznecov Y., Maksimova N., Tekst v stanovlenii: oppoziciya ',,narrativ-mentativ» [Text in Its Foundation: Opposition „Narrative-Mentative”], „Kritika i semiotika”, № 11, 2007, s. 54-67.

Maksimova N., Ponimanie $v$ dialoge: tekstovye modeli mentativa, [Understanding the Dialogue: Textual Models of Mentative], Novosibirsk 2012, [v:] Elektronnyj resurs: https:// www.metod-kopilka.ru/tekstovaya_kultura_modeli_rassuzhdeniya_v_russkom_tekste._m onografiya-26564.htm (01.03.2019).

Maslakov A., Nositel'vyskazyvaniya v poe'ticheskix esse O. E. Mandelshtama i M. Y. Cvetaevoj [Statement Carrier in Poetic Essays of O. E. Mandelshtam and M.Y. Tsvetaeva], „Izvestiya vuzov. Severo-Kavkazskij region. Obshchestvennye nauki”, 2010, № 6, s. 120-123.

Matsevko-Bekerska L., Typolohiia naratora: komunikatyvni aspekty khudozhnoho dyskursu [Narrator Typology: Communicational Aspects of Artistic Discourse], „Naukovyi visnyk Mykolaivskoho natsionalnoho universytetu imeni V. O. Sukhomlynskoho. Filolohichni nauky (literaturoznavstvo)”, № 8, 2011, [v:] Elektronnyi resurs: http://litzbirnyk.com.ua/ wp-content/uploads/2013/11/31.4.8.pdf (01.03.2019).

Proxorov G., Poe'tika xudozhestvenno-publicisticheskogo edinstva (na materiale literatury perioda klassicheskogo posttradicionalizma) [Poetics of Artistic and Publicist Unity (Based on Classic Post-Traditionalism Period in Literature], avtoref. ... d-ra filol. nauk, Moskva 2013.

Protsiuk S., Tini ziavliaiutsia na svitanku [Shadows Appear at Dawn], Lutsk: Tverdynia, 2011.

Tyupa V., O granicax narratologii [On Limits of Narratology], „Problemy narratologii i opyt formalizma / strukturalizma", Sankt-Peterburg 2008, [v:] Elektronnyj resurs: http://papusha.at.ua/tiupa-o_granicax_narratologii.doc (02.03.2019).

Shevchenko T., Ese yak dyskursyvna praktyka: do postanovky problem [Essay as a Discursive Practice: to the Problem Statement], Sribnyi vik: dialoh kultur, zb. nauk. st. za mater. IV Mizhnar. nauk. konf., prysv. pamiati prof. S. P. Iliova, Odesa 2018, s. 290-303.

Shevchenko T., Udovol'stvye ot chteniya e'sse ili o prichinax vostrebovaniya zhanra [Pleasure from Reading Essays or on the Reasons Why this Genre is So Relevant], Czas wolny, rozrywka, używky w najnowszej literaturze rosyjskiej, pod redakcją L. Kality, Gdańsk: Wydwo Un-tu Gdańskiego, 2018, s. 147-163.

Shmyd V., Narratologiya [Narratology], Moskva: Yazyki slavyanskoy kul'tury, 2003.

Baroni R., Françoise R., Narrative Sequence in Contemporary Narratology, Columbus: The Ohio State University Press, 2016.

Genette G., Figures of Literary Discourse, New York 1982.

Nycz R., Literatura nowoczesna: cztery dyskursy (tezy), Teksty Drugie, 2002, 4.

Prince G., Narratology: The Form and Function of Narrative, Berlin 1982. 
Todorov Tzv., Grammaire du Décaméron, Paris: Mouton, 1969.

Wolf W., Das Problem der Narrativitat in Literatur, bildender Kunst und Musik: Ein Beitrag $z u$ einer intermedialen Erzahltheorie, Erzahltheorie transgenerisch, intermedial, interdisziplinar, hrsg. V. Nunning, A. Nunning, Trier 2002. 